\title{
PERSEPSI PRAKTISI PENYIARAN TERHADAP REGULASI PENYIARAN DI INDONESIA: STUDI KASUS PROGRAM EMPAT MATA DAN BUKAN EMPAT MATA DI TRANS7
}

\author{
Rahmat Edi Irawan \\ Jurusan Marketing Communication, Fakultas Ekonomi dan Komunikasi, BINUS University \\ Jln. K.H. Syahdan No. 9, Palmerah, Jakarta Barat 11480
}

\begin{abstract}
Broadcasting regulation is one interesting thing to be observed in Indonesia's television industry development. One television program that mostly having violation of the regulation is Empat Mata which continued with Bukan Empat Mata broadcasted by Trans7. This supports the researcher to do research about how the exact perception of broadcasting practitioners towards broadcasting regulation in Indonesia. The result of qualitative research, which collects data through observation and literature study, shows there is lack of knowledge in broadcasting practitioners about Indonesia's Broadcasting Commission (KPI) and broadcasting regulation in Indonesia. Besides less socialization, multi-interpretation troubles in some regulations are the probable cause of increasing numbers of violation towards broadcasting regulations. As preventing action, it needs to have open dialog between KPI and broadcasting practitioners as bridging communication of their different authorities, which would be useful to increase quality of television show in Indonesia.
\end{abstract}

Keywords: broadcasting regulation, KPI, broadcasting practitioners

\begin{abstract}
ABSTRAK
Regulasi penyiaran menjadi salah satu hal yang paling menarik untuk diamati dalam perkembangan industri televisi di Indonesia. Salah satu program televisi yang sering melakukan pelanggaran tersebut adalah Empat Mata yang dilanjutkan dengan Bukan Empat Mata yang ditayangkan Trans7. Hal itulah yang mendorong peneliti ingin meneliti tentang bagaimana sebenarnya persepsi praktisi penyiaran terhadap regulasi penyiaran di indonesia. Hasil penelitian kualitatif yang pengumpulan datanya lewat observasi dan studi pustaka ini menunjukkan masih sedikitnya pengetahuan praktisi penyiaran tentang KPI dan regulasi penyiaran di Indonesia. Selain itu, masalah multitafsir pada beberapa aturan main dalam regulasi penyiaran, juga menjadi penyebab kenapa masih sering terjadi pelanggaran yang dilakukan praktisi penyiaran terhadap regulasi penyiaran. Untuk mengatasi hal tersebut, dibukanya ruang dialog antara KPI dan praktisi penyiaran menjadi salah satu jalan menjembatani perbendaan kepentingan di antara mereka, yang tentu akan berguna untuk peningkatan kualitas tayangan televisi di Indonesia.
\end{abstract}

Kata kunci: regulasi penyiaran, KPI, praktisi penyiaran 


\section{PENDAHULUAN}

\section{Latar Belakang}

Tumbangnya kekuasaan Orde Baru pada tahun 1998 membawa perubahan besar dalam industri penyiaran di Indonesia. Jika sebelumnya, Soeharto mengontrol dengan ketat semua institusi penyiaran, maka pasca kekuasaannya, banyak individu atau institusi berupaya untuk mendirikan lembaga penyiaran, sebagai bentuk ekspresi kebebasan menyebarkan informasi yang dulu nyaris tidak didapatkan. Tidak heran, jika saat ini di industri pertelevisian terdapat 10 stasiun televisi swasta nasional dan ratusan televisi lokal di 33 propinsi seluruh Indonesia. Jumlah itu belum termasuk televisi komunitas yang jumlahnya mencapai puluhan ditambah satu stasiun televisi publik, Televisi Republik Indonesia (TVRI) yang bersiaran di Jakarta dan beberapa kota besar lainnya.

Banyaknya stasiun televisi tidak dipungkiri menyebabkan terjadinya persaingan di antara stasiun televisi dan praktisi penyiaran itu sendiri. Mereka berlomba-lomba untuk membuat atau membeli serta menyiarkan program-program terbaik yang diinginkan penonton, baik program program hiburan maupun informasi. Bagi stasiun televisi swasta, program adalah hidup matinya televisi. Melalui program mereka ditonton dan dikenal penontonnya. Bahkan, lewat jumlah dan karakteristik penonton di sebuah program, akan ada pihak ketiga yang memasang iklan di stasiun televisi tersebut. Artinya, keberhasilan sebuah program yang ditandai dengan jumlah penonton sebanyak-banyaknya, akan memudahkan mereka untuk mendapatkan iklan, yang nantinya akan merupakan sumber pemasukan utama bagi stasiun televisi swasta.

Keinginan semua stasiun televisi swasta untuk mendapatkan jumlah penonton sebanyakbanyaknya menyebabkan kompetisi atau persaingan antar stasiun televisi, terutama stasiun televisi swasta nasional, menjadi amat ketat. Mereka akan selalu berbuat apa saja untuk menghasilkan produksi program terbaik dan menyiarkannya di waktu yang terbaik pula bagi mereka. Persaingan itu pula yang menyebabkan tidak jarang stasiun televisi melanggar berbagai regulasi penyiaran yang berlaku di Indonesia. Terjadinya perbenturan kepentingan antara keinginan stasiun televisi swasta untuk memproduksi atau membeli program yang dapat menarik penonton sebanyak-banyaknya, dengan regulasi penyiaran yang bertujuan untuk melindungi masyarakat dari dampak media massa, merupakan fenomena umum yang bukan saja terjadi di Indonesia tetapi juga terjadi di banyak negara lainnya. Pada satu sisi, industri pertelevisian tidak bisa melepaskan diri dari kepentingan kapitalisme atau pemilik modal, yang berusaha untuk mendapatkan keuntungan sebesar-besarnya dari modal yang sudah dikeluarkannya. Sementara pada sisi yang lain yang terkadang saling bersebrangan, ada kepentingan publik yang juga harus dihormati atau dijaga hak-haknya.

Salah satu program yang paling sering melakukan pelanggaran terhadap regulasi penyiaran menurut catatan Komisi Penyiaran Indonesia (KPI) sebagai lembaga independen yang menjadi regulator regulasi penyiaran di Indonesia adalah program Bukan Empat Mata yang mulai ditayangkan Trans7 pada tahun 2006, dan kemudian dilanjutkan dengan program Bukan Empat Mata yang hadir menggantikannya sejak tahun 2009. Saat masih bernama Empat Mata program talk show hiburan ini, tercatat 4 kali mendapat peringatan tertulis dari KPI Pusat karena melakukan pelanggaran terhadap Pedoman Perilaku Penyiaran dan Standar Program Siaran (P3SPS) Tahun 2004” sebagai regulasi tambahan bagi industri dan praktisi penyiaran ketika itu di luar UU Nomor 32 Tahun 2002 Tentang Penyiaran. Teguran pertama hingga ketiga yang diberikan pada 5 Mei 2007, 27 September 2007 dan 25 Agustus 2008 semuanya disebabkan karena program tersebut dianggap melanggar pasalpasal yang berkaitan dengan norma kesopanan dan kesusilaan. Sementara pelanggaran keempat, Bukan Empat Mata dipersalahkan karena melanggar pasal 28 ayat 3 dan 4 serta pasal 36 P3SPS Tahun 2007, tentang pelarangan bagi lembaga penyiaran yang menyiarkan adegan kekerasan. Kesalahan terakhir yang menyebabkan program tersebut akhirnya dihentikan penayangannya 4 November 2008. 
Selanjutnya, saat berganti nama menjadi program Bukan Empat Mata tercatat pula program tersebut 4 kali menerima peringatan tertulis dari KPI karena melakukan pelanggaran terhadap P3SPS Tahun 2007. Teguran pertama diterima pada 6 Mei 2009, karena pelanggaran norma kesopanan dan kesusilaan dalam bentuk dialog dan celutukan yang mengarah pada hal-hal yang berkaitan dengan seks. Berikutnya, pada 15 Juni 2009, Bukan Empat Mata mendapat hukuman dari KPI berupa pengurangan frekuensi tayang dari 5 menjadi 3 kali seminggu, akibat pelanggaran pasal 13 P3SPS Tahun 2007, berupa pelarangan adanya kata-kata bermakna jorok/mesum/cabul/vulgar dalam program siaran. Teguran tertulis berikutnya diterima Bukan Empat Mata pada 30 Desember 2009, karena host program tersebut, Tukul Arwana dituduh melakukan pelecehan seksual, dengan sengaja memegang bagian belakang tubuh co-host, Bella Saphira. Peringatan tertulis terakhir diterima Bukan Empat Mata pada 11 Juni 2010, karena adanya adegan presenter meminum wine dengan membaca basmalah, sehingga dianggap melanggar pasal 7 tentang larangan merendahkan nilai-nilai agama yang ada dalam regulasi terbaru, P3SPS Tahun 2009.

Melihat banyaknya teguran akibat pelanggaran terhadap regulasi penyiaran yang dilakukan program Bukan Empat Mata dan Bukan Empat Mata, tentu menjadi hal yang sangat menarik untuk mengetahui bagaimana sebenarnya persepsi manajemen televisi swasta, dalam hal ini, Trans7 menghadapi respon atau teguran dari KPI akibat pelanggaran regulasi yang mereka lakukan di program Bukan Empat Mata dan Bukan Empat Mata sepanjang tahun 2006-2010. Penelitian terhadap program Bukan Empat Mata dan program Bukan Empat Mata nantinya diharapkan dapat menjadi langkah awal bagi penelitian yang lebih komprehensif. Pertanyaan penelitian yaitu bagaimana sebenarnya sikap dan strategi manajemen televisi swasta menghadapi regulasi penyiaran di Indonesia.

\section{Kajian Pustaka}

Definisi komunikasi massa yang paling sederhana dikemukakan Vivian (2008), menyatakan bahwa komunikasi massa adalah proses penggunaan sebuah medium massa untuk mengirimkan pesan kerpada audien yang luas untuk tujuan memberi informasi, menghibur dan mendidik. Medium massa yang yang dimaksud adalah televisi atau koran. Lebih lanjut Vivian menyatakan bahwa, sama dengan komunikasi jenis lainnya, seperti komunikasi interpersonal dan komunikasi kelompok, yang tetap mengharuskan adanya pengirim pesan, pesan itu sendiri maupun mereka yang menerima pesan. Namun, berbeda dengan bentuk komunikasi lainnya, komunikasi massa digunkannya media massa untuk menyampaikan pesan dan adanya jumlah penerima pesan yang banyak dan beragam.

Dalam Ardianto (2004), fungsi komunikasi massa yang dikemukakan oleh Lasswell yakni, (1) fungsi pengawasan (2) fungsi korelasi (3) fungsi pewarisan sosial. Sama seperti pendapat Lasswell, Charles Robert Wright (1988) menambah fungsi hiburan dalam fungsi komunikasi massa.

Sedangkan fungsi komunikasi massa yang dikatakan oleh Dominick, dalam bukunya Dynamics of Mass Communications adalah sebagai berikut seperti dikutip oleh Elvinaro adalah: (1) surveillance (pengawasan), fungsi pengawasan komunikasi massa dibagi dalam dua bagian yaitu fungsi pengawasan peringatan dan fungsi pengawasan instrumenta. Pada fungsi pengawasan peringatan yang dilakukan oleh media untuk menyampaikan informasi berupa ancaman yang perlu diketahui oleh khalayak. Sementara pada fungsi pengawasan instrumental adalah penyampaian atau penyebaran informasi yang memiliki kegunaan atau dapat membantu khalayak dalam kehidupan sehari-hari.

(2) Interpretation (penafsiran), media massa tidak hanya memasok fakta dan data tetapi juga memberi penafsiran terhadap kejadian-kejadian penting. Tujuan penafsiran media ini adalah untuk mengajak khalayak untuk memperluas wawasan dan membahasnya lebih lanjut. (3) Linkage (pertalian), media massa dapat menyatukan anggota masyarakat yang beragam sehingga membentuk pertalian berdasarkan kepentingan yang sama tetapi terpisah secara geografis atau jarak fisik. (4) 
Transmission of value (penyebaran nilai-nilai), fungsi ini disebut juga socialization (sosialisasi). Sosialisasi mengacu kepada cara, di mana individu mengadopsi perilaku dan nilai kelompok. Media massa mewakili gambaran masyarakat itu ditonton, didengar, dan dibaca. Media massa memperlihatkan kepada kita bagaimana mereka bertindak , bagaimana mereka bersikap sesuai dengan nilai-nilai yang dipercaya, serta bertindak sebagai anggota masyarakat secara efektif.

(5) Entertainment (hiburan), media massa adalah sarana yang banyak menyita waktu luang semua golongan usia, dengan difungsikannya sebagai alat hiburan dalam rumah tangga. Sifat estetikanya dituangkan dalam bentuk lagu, lirik, bunyi, gambar, dan bahasa, sehingga mampu membawa khalayak pada situasi menikmati huburan seperti halnya hiburan lain.

Jika dilihat dari fungsi komunikasi massa di atas, maka penelitian yang mengangkat program Bukan Empat Mata dan Bukan Empat Mata yang ditayangkan Trans7 di atas lebih cocok atau pas sebagai fungsi komunikasi massa sebagai alat hiburan. Kedua program tersebut kebetulan memang dibuat untuk lebih banyak untuk menghibur penontonnya (entertainment). Bahkan, jika dilihat secara genre program, Bukan Empat Mata dan Bukan Empat Mata memang dikategorikan sebagai program hiburan di televisi.

Secara sederhana pengertian dari dari program televisi adalah rangkaian pesan yang dibuat pemilik dan pengelola stasiun televise kepada penontonnya. Jadi program televisi adalah semua tayangan yang bisa kita lihat dari sebuah stasiun televisi. Program televisi adalah jualan setiap stasiun televisi untuk dapat menarik penonton dan pemasang iklan.

Program televisi jika dilihat dari sumbernya dapat dibagi dalam dua kelompok, yaitu programprogram yang dibuat sendiri (in-house production program) dan program-program yang dibeli (akuisisi program). Pada in house production, semua program merupakan hasil kreatifitas dan karya dari lingkungan internal sebuah stasiun televisi. Sementara pada akuisisi program, semua program tersebut berasal dari pembelian, baik produksi dalam negeri (lokal akuisisi) maupun dari distributor program di luar negeri (Morissan, 2008).

Stasiun televisi setiap harinya menyajikan berbagai jenis program yang jumlahnya sangat banyak dan jenisnya sangat beragam. Pada dasarnya, apa saja yang bisa dijadikan program acara untuk tayang di televisi asalkan menarik dan disukai oleh penonton, dan selama tidak bertentangan dengan norma kesopanan dan kesusilaan, serta hukum dan peraturan yang berlaku.

Berbagai jenis program televisi secara garis besar dapat dikelompokkan menjadi dua bagian besar, yaitu program informasi (jurnalistik) dan program hiburan (artistik). Program informasi adalah program yang lebih berorientasi untuk memberikan info atau berita kepada penontonnya yang semuanya harus berasal dari sebuah fakta atau kejadian yang benar-benar terjadi. Program informasi terbagi atas jenis, yaitu berita keras (hard news) dan berita ringan (softnews). Berita keras merupakan laporan berita terkini yang harus segera diberitakan, biasanya bentuk programnya adalah bulletin atau breaking news. Sementara untuk berita ringan (softnews) merupakan laporan yang peliputan atau penyampaian tidak terikat dari segi waktu atau bisa dilakukan kapan saja (timeless), biasanya programnya dalam bentuk feature, magazine atau dokumenter (Baksin, 2009).

Sementara program lainnya adalah kategori program hiburan. Pada program hiburan orientasinya adalah memberikan hiburan kepada penontonnya, baik sesuatu yang yang faktual atau bisa juga yang non faktual. Program hiburan terbagi atas dua kelompok besar, yaitu drama dan non drama. Program-program drama dapat kita temukan saat ini di tayangan televisi dalam bentuk film, sinetron, ftv, series, sketsa dan lain-lain. Sementara untuk program non drama terdiri atas jenis program musik, game show, talent show, komedi, reality show, dan variety show dan lain-lain. 
Program talk show yang menjadi kajian dalam penelitian ini sebenarnya bisa ditemukan di semua jenis kelompok program, baik informasi maupun hiburan. Talk show atau program wicara di televisi adalah sajian program yang menyajikan pembicaraan seseorang atau lebih mengenai sesuatu yang menarik, yang sedang hangat dibicarakan di masyarakat. Dari pengertian tersebut, jelas bahwa program talk show, bisa ditemukan baik di program berita maupun hiburan (Wibowo, 2007). Program talk show masuk dalam program informasi, jika memang orientasi program tersebut lebih menitikberatkan pada pembicara untuk memberikan informasi atau berita kepada penontonnya, seperti pada program Jakarta Lawyers Club atau Debat di TV One. Sementara untuk program yang talk show yang orientasinya lebih banyak untuk memberikan hiburan kepada penontonnya adalah tetap dimasukkan dalam program hiburan. Pada talk show jenis ini, informasi bukan lagi sebagai jualan utama program, melainkan perbincangan yang menghibur, lucu, segar dan tidak formal menjadi sesuatu yang diberikan kepada penontonnya. Hal seperti itulah yang terjadi pada program Bukan Empat Mata dan program Bukan Empat Mata yang menjadi kajian dalam penelitian ini.

Program Bukan Empat Mata adalah program yang ditayangkan Trans7, ketika bergabung dengan Trans Corp, pada Mei 2006. Mulanya program tersebut lebih ditujukan untuk tayangan lakilaki dewasa, sebagai tayangan perbincangan dengan tema-tema masalah orang dewasa. Tanpa diperkiarakan sebelumnya, program yang punya konsep menghadirkan acara dialog yang menghibur dengan tampilan host atau presenter (Tukul Arwana) yang punya kemampuan pas-pasan ini, mendapat sambutan yang luar biasa dari masyarakat. Stasiun televisi TV7 yang kemudian berganti nama menjadi Trans7, terangkat popularitasnya karena punya program yang menjadi program favorit penonton dan pemasang iklan. Semula program ini tayang sekali seminggu, meningkat menjadi 2 kali seminggu dan terus meningkat menjadi 3 kali, bahkan hingga 5 kali seminggu.

Berbicara tentang televisi dan program-programnya, tentu tidak akan lepas dari regulasi penyiaran yang ada di sebuah negara. Secara umum pengertian dari regulasi adalah upaya untuk mengendalikan manusia atau masyarakat dengan berbagai macam aturan atau pembatasan. Regulasi biasanya diamanatkan oleh negara untuk memungkinkan masyarakat berjalan, tanpa adanya saling merugikan di antara masyarakat sendiri, atau dengan pemerintah atau negara itu sendiri. Dalam wujudnya yang paling sederhana, regulasi biasanya berbentuk artefak atau laporan pengaturan dan pelaksanaan dari kebijakan tersebut. Regulasi dapat dilakukan dalam berbagai bentuk, seperti pembatasan melalui aturan hukum yang dilakukan pemerintah, regulasi pengaturan diri oleh suatu asosiasi atau perkumpulan dan lainnya. Jadi, selain menyangkut aturan-aturan main yang disepakati atau diputuskan, regulasi juga biasanya menyangkut siapa regulator atau mereka yang mengawasi dijalankannya aturan-aturan main yang telah disepakti atau diputuskan tersebut.

Lalu, mengapa regulasi penyiaran amat dibutuhkan? Barangkali untuk menjawab pertanyaan tersebut, kita harus melihat terlebih dahulu apa yang dimaksud dengan penyiaran itu sendiri. Penyiaran atau broadcast dalam bahasa Inggris dapat diartikan sebagai penyaluran informasi atau pesan yang dikirimlan melalui spectrum frekuensi radio. Jadi, diperlukan alat pengirim atau penerima informasi atau pesan yang menafaatkan frekuensi gelombang radio yang ada di udara. Melalui frekuensi gelombang radio tersebut, semua informasi atau pesan bisa dipindahkan atau ditransfer dari si pengirim kepada penerimanya (Morissan, 2008).

Dalam UU Penyiaran Nomor 32 Tahun 2002, penyiaran adalah kegiatan pemancarluasan siaran melalui sarana pemancaran dan/ atau sarana transmisi di darat, di laut, atau di antariksa dengan menggunakan spektrum frekuensi radio (sinyal radio) yang berbentuk gelobang elektromagnetik, yang merambat melalui udara, kabel, dan atau media lainnya untuk dapat diterima secara serentak dan bersamaan oleh masyarakat dengan perangkat penerima siaran (Mufid, 2005).

Untuk bisa menjalankan kegiatan penyiaran maka harus memenuhi lima persyaratan sebagai berikut, yaitu; harus tersedia spectrum frekuensi radio, harus ada sarana pemancaran atau transmisi, harus adanya perangkat penerima siaran, harus adanya siaran, dan harus dapat diterima secara serentak 
atau bersamaan. Jika dilihat dari kelima persyaratan tersebut di atas, persayaratan pertama, atau frekuensi radio adalah syarat yang menmggunakan area atau milik publik. Sebab, tidak ada orang atau kelompok yang secara mutlak bisa menguasai ruang publik seperti udara, karena itu merupakan suatu hal yang disediakan oleh Tuhan untuk makhluk ciptaannya.

Melihat kenyataan bahwa terus digunakannya sebuah ruang publik untuk kegiatan penyiaran di atas, maka sebuah aturan main atau regulasi untuk memanfaatkan ruang publik dalam kegiatan penyiaran itu menjadi mutlak diperlukan. Setidaknya ada tiga hal yang menyebabkan kenapa regulasi penyiaran amat diperlukan, yaitu yang pertama, kegiatan penyiaran termasuk penggunaan frekuensi gelombang radio di udara merupakan bagian dari hak azasi manusia, terutama pada kebebasan manusia untuk memperoleh, menyebarluaskan pendapatnya tanpa intervensi, termasuk dari pemerintah. Namun tentu saja semua manusia harus memperoleh hak yang fair tanpa mengganggu hak orang lain (Mufid, 2005; 97-104)

Permasalahannya ada keterbatasan frekuensi gelombang penyiaran tersebut di udara bebas. Karena keterbatasan tempat untuk menempatkan dan mengirimkan pesan di frekuensi gelombang radio tersebut, maka perlu diatur siapa yang berhak dan siapa yang tidak berhak menggunakan frekensi gelombang rado yang terbatas tadi. Sebagai gambaran mudah, jika dalam komunikasi ada dua orang yang sama-sama bicara, mungkin pesan tidak akan mungkin tersampaikan dengan baik. Jadi, perlu diatur siapa yang berhak mengirim pesan dan siapa yang posisinya hanya menerima pesan.

Kedua, dalam alam demokrasi seperti sekarang ini, maka perlu dijaminnya keberagaman bagi masyarakat dalam menerima pesan. Secara lebih luas, dalam masyarakat yang plural dan beraneka ragam seperti di Indonesia ini, maka masyarakat berhak memilih atas apa program siaran yang akan mereka mau dan tidak mau mereka terima. Selain itu, di setiap daerah, komunitas atau kelompok masyarakat tertentu, ada nilai atau norma-norma yang berlaku yang mungkin berbeda dengan daerah, komunitas atau kelompok masyarakat lainnya. Alasan keberagaman tersebutlah yang menjadi alasan kenapa regulasi penyiaran menjadi sangat diperlukan (Mufid, 2005).

Sementara alasan terakhir adalah menyangkut prinsip ekomoni, yaitu masalah monopoli dalam kepemilikan media massa penyiaran. Jadi meskipun seseorang mungkin saja karena modalnya yang besar mampu membeli atau membangun perusahaan media massa, sehingga dapat memonopoli kepemilikan media massa tersebut. Namun, area publik berupa frekuensi radio menjadi hal yang tidak mungkin dibeli, dan menjadi pencegah monopoli kepemilikan di media massa yang menggunakan frekuensi gelombang radio. Sebab, dengan regulasi penyiaran, bisa diatur secara merata kepemilikan siapa saja yang berhak menggunakan frekuensi gelombang radio tersebut.

Di Indonesia, regulasi penyiaran diatur melalui UU Nomor 32 Tahun 2002. Dalam UU tersebut, diatur siapa saja yang terlibat dalam penggunaan frekuensi gelombang radio atau kegiatan penyiaran di Indonesia. Termasuk di dalamnya adalah diamanatkannya pembentukan sebuah lembaga pengawas penyiaran indenpenden, yang anggotanya merupakan wakil-wakil masyarakat yang dipilih oleh DPR. Lembaga yang diberi nama Komisi Penyiaran Indonesia (KPI) tersebut selain mengontrol kegiatan penyiaran juga membuat aturan main tentang apa yang boleh dan tidak boleh dilakukan atau kode etik penyiaran bagi mereka yang terlibat dalam kegiatan penyiaran di Indonesia, termasuk menjatuhkan sangsi jika terjadi pelanggaran terhadap kode etik penyiaran tersebut.

Jadi regulasi penyiaran yang dimaksud dalam penelitian ini adalah berupa aturan main yaitu UU Nomor 32 Tahun 2002 tentang Penyiaran. Selain itu juga kode etik penyiaran yaitu berupa Pedoman Perilaku Penyiaran dan Standar Program Siaran (P3SPS) yang telah 3 kali dikeluarkan oleh KPI, pada tahun 2004, 2007 dan 2009. Semua regulasi itulah yang menjadi acuan bagi mereka yang terlibat dalam kegiatan penyiaran di Indonesia, sehingga juga ikut dimasukkan dalam fokus di penelitian ini. 
Menyangkut kegiatan penyiaran itu, beberapa teori dalam kajian ilmu lainnya, ada beberapa hal yang bisa ditelaah untuk memperkaya tulisan ini. Pertama adalah Teori Marx, yang berasal dari pendapat Karl Marx dan Fredrich Angels pada abad ke-19. Teori tentang struktur kelas di masyarakat ini sebenarnya adalah pemikiran Marx tentang prinsip-prinsip ekonomi, namun pada akhirnya punya pengaruh luas dalam berbagai bidang kehidupan, termasuk komunikasi. Menurut marxisme, ada sekelompok dalam masyarakat yang memiliki modal sehingga menguasai alat-alat produksi, yang akhirnya menguasai struktur atas atau menjadi kelas atas dalam masyarakat. Mereka ini yang akan terus menindas kelas lainnya untuk mempertahankan apa yang mereka miliki tersebut.

Dalam ilmu komunikasi, teori Marx di atas dimasukkan dalam kelompok teori kritis yang memandang media massa yang kebanyakan dimiliki oleh kelas pemilik modal, bekerja dengan tujuan utama untuk memberikan pembenaran dan mendukung kondisi status quo dengan mengorbankan masyaraat lainnya. Dengan demikian, isi media massa hanya untuk keuntungan dan kepentingan si pemiliki media massa tersebut saja. Bahkan, secara sinis Marx berpendapat bahwa apa yang disampaikan media massa sejak awal dibuat dan disampaikan kepada khalayak atau audien dengan satu tujuan, yaitu membela kepentingan paham kapitalisme (Morissan, 2008).

Jika dikaitkan dengan industri televisi saat ini, maka kita akan melihat bahwa teori Marx di atas akan menunjukkan bahwa pemilik dan pengelola stasiun televisi akan selalu berusaha untuk membuat atau menyiarkan program-program yang akan memberikan keuntungan untuk mereka. Artinya, mereka akan berusaha agar program-program yang ditayangkan ditonton sebanyak mungkin penonton atau punya rating dan share program-program tersebut tinggi sehingga menarik para pemasang iklan. Jadi, mereka akan berusaha mati-matian untuk mempertahakan menayangkan program yang punya rating dan share tinggi, seperti Bukan Empat Mata dan Bukan Empat Mata di Trans7.

Teori lainya yang sebenarnya juga masih sangat dipengaruhi oleh teori marxisme adalah teori ekonomi politik. Dalam pandangan teori ekonomi politik seperti yang disampaikan Herb Schiller disebutkan bahwa pengaruh korporasi ada di hampir tiap aspek masyarakat, dari hal-hal yang sederhana, seperti menu sehari-hari kita dan pakaian yang kita kenakan hingga hal-hal yang berskala besar seperti cara kita berkomunikasi satu sama lain. Lebih lanjut, teori ini menelaah tentang bagaimana batasan-batasan perekonomian menentukan atau membiaskan bentuk budaya yang dihasilkan dan disebarkan melalui media massa (Baran, 2010).

Jika dikaitkan dengan program-program yang ditayangkan di televisi, maka akan kita lihat bahwa semua pesan atau program yang ditayangkan oleh televisi sudah disaring terlebih dahulu oleh pemilik atau pengelola stasiun televisi, sehingga hanya yang benar-benar sesuai dengan kepentingan ekonomi dan politik mereka saja yang ditayangkan. Sebaliknya, pesan atau isi program yang tidak menguntungkan secara ekonomi dan politik, tidak akan mereka tayangkan.

Sementara teori lain yang juga digunakan untuk penelaahan dalam tulisan ini adalah teori komodfikasi budaya yang merupakan bagian dari ilmu komunikasi. Teori ini memfokuskan penelaahannya pada bagaimana media sebagai industri yang mengkhususkan diri pada produksi dan distribusi komoditas kebudayaan. Teori ini menegaskan bahwa pengusaha media massa membangun strategi mereka untuk menciptakan komoditas budaya yang menarik secara universal. Artinya, media secara sengaja memilih komoditas kebudayaan mana yang akan mereka tampilkan untuk kepentingan mereka. Saat menonton televisi, sebenarnya penonton sedang berhadapan dengan sebuah kebudayaan yang sudah dipaketkan (Subandy, 2004).

Jika dikaitkan dengan program-program televisi, maka terlihat bahwa teori komodifikasi budaya memang sangat terlihat, karena hanya budaya-budaya tertentu saja yang dipilih untuk dimasukkan dalam tayangan televisi. Artinya, setiap program yang disiapkan oleh stasiun televisi sudah merupakan hasil modifikasi budaya yang memang dianggap cukup menjual, mampu menarik 
penonton maupun pemasang iklan. Isi program merupakan suatu hal yang sudah direkayasa sedemikian rupa sehingga menarik minat orang untuk menontonnya. Apa yang disajikan merupakan bagian dari show yang penuh rekayasa yang bertujuan untuk mengumpulkan sebanyak-banyaknya penonton. Bahkan, dalam suatu tontonan tentang liputan tentang penggrebekan teroris misalnya, disajikan oleh televisi seperti menyajikan opera sabun (Subandy, 2004).

\section{HASIL DAN PEMBAHASAN}

Pengetahuan tentang regulasi penyiaran di Indonesia memang terbilang minim bagi pengelola stasiun televisi swasta. Regulasi dan regulator yang independen adalah sesuatu yang baru dalam dunia penyiaran Indonesia di awal abad ke-21. Di masa Orde Baru, regulasi dan regulator adalah wewenang penuh Departemen Penerangan, yang menjalankan tugas dan wewenangnya lebih berdasarkan keinginan penguasa politik ketika itu. Tumbangnya rezim Soeharto membuat permasalahan penyiaran, menjadi sesuatu yang harus dibicarakan bersama masyarakat untuk pengaturannya. Maka, sebuah lembaga independen pengawas penyiaran dan aturan main dalam dunia penyiaran yang mengakomodir semua kepentingan, dianggap mendesak untuk didirikan mengatur segala hal yang terkait dengan penyiaran yang ada di Indonesia.

Menyusul diberlakukannya Undang-Undang Nomor 32/ 2002 yang menjadi landasan berpijak sistem penyiaran yang ada di Indonesia, maka dibentuklah lembaga indenpenden pengawas penyiaran. Komisi Penyiaran Indonesia (KPI) pada tagun 2004. KPI merupakan wakil-wakil dari semua elemen masyarakatyang dipilih DPR, sehingga dianggap sebagai lembaga independen, yang lepas dari campur tangan pemerintah. Barangkali, karena bukan institusi pemerintah, kehadiran lembaga ini kurang mendapat sambutan industri penyiaran yang lebih menghendaki aparat birokratis yang mudah dikdekati (Mufid, 2005; 166). Tidak heran, banyak kalangan penyiaran (broadcaster) yang masih tidak mengetahui keberadaan KPI, termasuk apa saja tugas-tugasnya. Apalagi, pro dan kontra kehadiran KPI di kalangan pemilik dan top manajemen industri penyiaran, menyebabkan sosialisai kehadiran KPI dan ruang lingkup tugas-tugasnya pada semua karyawan stasiun televisi lainnyam masih minim dilakukan. Kondisi seperti itulah yang dihadapi oleh team produksi Empat Mata, saat pertama mereka memulai program tersebut di tahun 2006.

Uniknya, meski tidak banyak mengetahui KPI dan ruang lingkup tugas institusi tersebut di awal pendiriannya, nama-nama komisioner yang ada di KPI cukup dikenal kalangan broadcaster. Mereka cukup akrab, bahkan menhetahui siapa saja komisioner yang duduk di KPI. Barangkali, hal tersebut terkait dengan latar belakang komisioner yang sebagian punya latar belakang profesi atau pekerjaan yang bersinggungan dengan dunia penyiaran. Bahkan, beberapa di antata mereka adalah mantan broadcaster yang sudah pensiun sebagai praktisi penyaiaran. Tidak heran, ketika terjadi beberapa kali teguran terhadap program Empat Mata, dengan mudahnya pihak manajemen Trans7 menghubungi lewat telepon sebagian anggota komisioner yang kebetulan sudah mereka kenal sebelum orang tersebut duduk sebagai konsioner KPI.

Minimnya tentang tugsas-tugas KPI pada akhirnya juga terlihat dari kekurang-pengetahuan praktisi penyiaran tersebut terhadap produk-produk yang dikeluarkan KPI. Seperti kita ketahui, tidak lama setelah diresmikan KPI membuat aturan main atau regulasi penyiaran di Indonesia, dalam bentuk Pedoman Perilaku Penyiaran dan Standar Program Siaran (P3SPS), yang pertama kali disahkan pada tahun 2004. Padahal, semua aspek program termasuk apa yang boleh dan tidak boleh ditayangkan di televisi, diatur dalam P3SPS tersebut. Jadi, jika ada sebuah tayangan mendapat teguran dari KPI, sebenarnya program tersebut melakukan pelanggaran terhadap P3SPS tersebut. Namun, sayangnya pengetahuan tentang produk-produk KPI tersebut masih sangat sedikit diketahui oleh para praktisi penyiaran, termasuk team produksi Bukan Empat Mata Trans7. 
Pengetahuan tentang produk-produk KPI, berupa regulasi penyiaran atau dalam bentuk P3SPS, yang sebenarnya mengatur secara detail tentang apa yang boleh dan tidak boleh yang ditayangkan televisi, harusnya menjadi pertimbangan utama dari semua pembuatan program. Program yang baik bukan saja harus ditonton banyak orang sehingga menjadi magnet bagi pemasang iklan, namun juga harus tidak melanggar berbagai aturan yang sudah ditetapkan KPI melalui P3SPS tersebut. Sejak diberlakukannya aturan-aturan main dalam P3SPS tersebut, selayaknya praktisi penyiaran mengetahui dan menjalankannya. Dalam kaitannya dengan vitalnya aturan main atau regulasi penyiaran dalam pembuatan sebuah program tersebut, ternyata masih sepotong-potong saja yang benar-benar dijalankan oleh para praktisi penyiaran, termasuk team produksi Empat Mata Trans7. Terbukti, mereka hanya takut melanggar aturan main jika dalam tayangannya banyak menampilkan sesuatu yang mengandung unsur vulgar atau bermuatan seks, yang memang menjadi salah satu yang diatur dalam regulasi penyiaran tersebut.

Padahal, jika dibuka dalam aturan main atau regulasi penyiaran berdasarkan P3SPS yang dikeluarkan KPI, regulasi tentang tayangan yang mengandung unsur vulgar atau bermuatan seks, hanya menjadi bagian kecil dari banyak regukasi tayangan yang diatur KPI. Masih ada jenis tayangan bernuansa mistis, kekerasan, agama, ras dan lainnya yang semuanya diatur dalam berbagai produk KPI, terutama produks-produk yang berkaitan dengan sistem regulasi penyiaran yang ada di Indonesia. Dalam banyak program, termasuk program Empat Mata dan Bukan Empat Mata di Trans7, justru teguran KPI juga terjadi pada kasus tayangan yang tidak berkaitan dengan tayangan yang mengandung unsur seks atau vulgar. Bahkan, saat Empat Mata terkena skorsing tidak boleh ditayangkan, episode yang menyebabkannya justru tayangan yang menampilkan adegan kekerasan, bukan seks.

Karena pengetahuan yang masih setengah-setengah tentang berbagai regulasi penyiaran atau dalam bentuk P3SPS yang dikeluarkan KPI yang menyebabkan banyak praktisi penyiaran yang terkaget-kaget saat mendapat teguran atau sanksi dari KPI yang diberikan KPI. Kondisi tersebut yang juga terjadi di program Empat Mata dan Bukan Empat Mata yang ditayangkan Trans7. Dari pra produksi, produksi maupun pasca produksi yang dilakukan team produksinya, mereka lebih berhatihati pada tayangan yang mengeksploitasi unsur seks atau vulgar. Mereka sangat concern sekali dengan tampilan, dialog atau apapun yang berkaitan dengan unsur seks tersebut. Sebaliknya, mereka tidak begitu detail awas melihat adanya tayangan yang ternyata mengandung unsur kekerasan atau melecehkan agama, suku atau ras tertentu.

Kurangnya sosialisasi dan kekurangpedulian praktisi penyiaran terhadap regulasi penyiaran yang dikeluarkan KPI membuat mereka juga tidak mengetahui bahwa program mereka sudah melanggar P3SPS tersebut. Mereka benar-benar baru mengetahui programnya menabrak apa yang terdapat dalam regulasi penyiaran, setelah mendapat teguran dari KPI. Hal tersebut yang dialami team produksi Empat Mata Trans7 yang hanya menerka-nerka tentang kenapa program mereka mendapat teguran tertulis dari KPI. Mereka juga hanya menebak-nebak, bagian mana di program mereka yang sebenarnya menjadi sorotan KPI kareka melanggar P3SPS. Bahkan, saat jatuh hukuman yang cukup berat, berupa larangan tidak boleh tayang program tersebut selama tiga bulan, masih ada di antara team produksi program tersebut yang belum benar-benar mengetahui apa kesalahan yang sudah mereka lakukan.

Akibat masih belum mengetahui secara pasti kesalahan yang mereka lakukan tersebut, jatuhnya hukuman atau sanksi dari KPI terhadap sebuah program atau stasiun televisi, selalu menimbulkan pro dan kontrak di kalangan praktisi penyiaran. Sebagian dari kalangan pertelevisian menganggap hukuman tersebut wajar dijauhkan mengingat memang ada bukti kesalahan yang mereka lakukan sendiri. Namun, justru tidak sedikit praktisi penyiaran yang menganggap KPI terlalu mengada-ada, bahkan memberatkan stasiun televisi karena menjatuhkan hukuman atau sanksi akibat perbuatan yang masih belum jelas kesalahannya. Seperti yang dilakukan manajeman stasiun televisi Trans7, yang menganggap hukuman atas tidak boleh tayangnya program Empat Mata selama tiga 
bulan adalah hukuman yang sangat berat. Hukuman tersebut sudah tidak lagi mendidik, karena seakan tidak ada lagi kesempatan memperbaiki tayangan tersebut.

Menyusul jatuhnya sanksi tersebut, pihak manajemen stasiun televisi Trans7 memang melakukan berbagai upaya untuk mengurangi beban berat akibat sanksi yang dijatuhkan kepada program Bukan Empat Mata tersebut. Mulai dari menolak hukuman yang dijatuhkan, meminta banding atas hukuman tersebut atau juga meminta keringanan hukuman karena mersa kesalahan seperti yang dilakukan seharusnya tidak dikategorikan sebagai sebuah kesalahan besar yang mengakibatkan tidak boleh tayangnya program tersebut. Namun di tengah upaya tersebut, pihak manajeman Trans7 ternyata juga melihat masih banyaknya kelemahan dalam pasal-pasal sanksi yang dijatuhkan sesuai dengan P3SPS atau regulasi penyiaran di Indonesia, yang bisa dimanfaatkan tanpa merugikan terlalu banyak kepentingan bisnis mereka. Celah inilah yang pada akhinya mereka manfaatkan dengan membuat program baru dengan format yang hampir sama, bahkan dengan nama yang hampir sama pula, yaitu program Bukan Empat Mata, yang boleh tayang, karena dianggap sebuah program baru. Munculnya program ini sempat membuat polemik, pro dan kontra terutama di kalangan komisoner KPI, tentang boleh tidaknya acara tersebut muncul, mengingat masa hukuman terhadap program Empat Mata yang tidak boleh tayang sebenarnya belum berakhir. Namun, dalam kenyataannya, karena tidak ada satu pasalpun yang melarang hal tersebut, akhirnya program Bukan Empat Mata yang dianggap sebagai penerus dari program sebelumnya Bukan Empat Mata tetap tayang tanpa halangan lagi sampai sekarang.

Belajar dari pengalaman beberapa kali mendapat teguran maupun hukuman, para praktisi penyiaran termasuk manajemen Trans7, berharap KPI bisa selalu melakukan dialog jika terjadi pelanggaran terhadap regulasi penyiaran yang mereka lakukan. Sebenarnya, saat ini setiap stasiun televisi bisa melakukan keberatan mereka atau melakukan klarifikasi jika terhjadi pelanggaran dalam program-program yang ditayangkan. Namun itu saja belum cukup, bagi pengelola stasiun televisi swasta dan praktisi penyiaran. Mereka berharap ke depannya, KPI membuka komunikasi atau dialog yang seimbang. Terkadang hukuman yang dijatuhkan, lebih berdasarkan interprestasi para komisioner di KPI atau lebih parahnya lagi karena adanya desakan dari sebagian masyarakat yang mungkin merasa keberatan atas sebuah tayangan. Selain itu, KPI hendaknya lebih jernih melihat apakah sebuah kesalahan itu dilakukan karena kesengajaan atau karena ketidaksengajaan, atau terkadang mungkin hanya sekedar kesalahan yang sebenarnya bukan dilakukan pengelloa stasiun televisi tersebut.

Kesalahan yang ditujukan pada tayangan Bukan Empat Mata, akibat salah seorang bintang tamu yang hadir di acara tersebut, yang tidak sengaja karena latah mengeluarkan kata-kata yang dianggap vulgar, barangkali bisa menjadi pelajaran bagi stasiun televisi maupun KPI sendiri dalam penegakan regulasi penyiaran di Indonesia. Meski memmang melanggar aturan main yang ada di P3SPS, KPI harusnya tetap melaihat bahwa stasiun televisi juga menjadi korban dari kesalahan bintang tamu tersebut. Terbukti, bintang tamu tersebut juga sudak menyampaikan permintaan maafnya, karena melakukan kesalahan di acara tersebut. Untuk itu, sebuah fórum dialog sebelum hukuman dijatuhkan memang perlu terus dilakukan, guna mengurangi kesalahan dalam menjatuhkan hukuman dan lebih fair ketika hukuman tersebut dijatuhkan.

Selain tetap membuka forum dialog sebelum hukuman atau sanksi diberikan kepada stasiun televisi, praktisi penyiaran juga meminta KPI meninjau kembali beberapa aturan main yang multi tafsir. Selama ini masih ada regulasi yang seolah-olah tidak tegas dan sulit dalam peenrapannya. Aturan main tentang tingkatan sanksi yang diberikan misalnya tiadk jelas dan rancu. Meski belum pernah mendapat teguran tertulis, bisa saja sebuah program langsung dilarang ditayangkan, jika dianggap melanggaran regulasi penyiaran, P3SPS tersebut. Sebaliknya, ada program yang berulangulang mendapat teguran tertulis, namun tetap biasa meneruskan siarannya. Beratnya hukuman terkadang, lebih banyak dikarenakan penafsiaran dari para komisioner KPI saja. Jelas, adanya regulasi yang multi tafsir tersebut bisa menimbulkan persepsi adanya kongkalingkong antara manajemen stasiun televisi dengan komisioner KPI. 
Akhirnya, bagaimana harusnya bentuk regulasi penyiaran dan hubungannya antara KPI dan stasiun TV, akan terus menjadi masalah yang menarik untuk diamati. Tarik menarik kepentingan, antara kepentingan mempertahakan bisnisnya bagi praktisi penyiaran dan menjaga kepentingan publik yang lebih besar bagi komisioner KPI, pasti akan terus terjadi di masa depan. Seharusnya, sebuah regulasi yang lebih komprehensif akan tetap dan harus dibutuhkan untuk melindungi semua kepentingan masyarakat atas praktek dari industri penyiaran yang ada di Indonesia, namun tanpa harus dipertimbangkan untuk tidak mematikan praktek dan kreatifitas dari industri penyiaran itu sendiri.

\section{PENUTUP}

Regulasi penyiaran di Indonesia menjadi masalah yang menarik untuk diamati pasca kekuasaan Orde Baru. Dibukanya partisipasi masayarakat yang lebih luas dalam industri pertelevisian, menyebabkan masalah aturan main, yang menyangkut boleh dan tidak bolehnya sebuah tayangan, menjadi kajian yang selalu dinamis untuk diikuti. Apalagi, dalam penentuan tentang aturan main tersebut, terlibat berbagai kepentingan yang saling berbeda, sehingga perdebatan atau issu tentang regulasi penyiaran selalu menjadi hal yang menarik. Pada satu sisi, praktisi penyiaran termasuk pengelola stasiun televisi swasta berupaya untuk menjaga program sebagai asset utama jualan mereka terhadap berbagai kemungkinan sanksi akibat melanggar berbagai aturan main dalam regulasi penyiaran di Indonesia, sementara di sisi yang lain, KPI sebagai regulator penyiaran berupaya menjaga kepentingan publik dari tayangan yang mungkin akan berdampak buruk bagi masyarakat. Salah satu kasus yang menarik untuk diamati karena terjadinya perang kepentingan di atas adalah program Bukan Empat Mata yang dilanjutkan dengan program Bukan Empat Mata yang ditayangkan Trans7 sejak tahun 2006 lalu. Tayangan ini tercatat yang paling banyak mendapat teguran atau sanksi dari KPI karena melanggar berbagai regulasi atau aturan main penyiaran yang terdapat dalam P3SPS. Bahkan, program tersebut sempat dihentikan penayangannya oleh KPI karena terbukti melakukan pelanggaran yang dianggap berat, sesuai dengan regulasi penyiaran tersebut. Meski demikian, kenyataannya, program ini tetap tayang dengan nama lain, namun tetap dengan isi maupun pengemasan yang nyaris sama. Kurangnya sosialisasi terhadap berbagai produk regulasi penyiaran yang dihasilkan KPI menjadi salah satu sebab, masih banyaknya kasus pelanggaran terhadap regulasi penyiaran, termasuk yang dilakukan program Bukan Empat Mata dan Bukan Empat Mata di Trans7. Apalagi, pada saat awal pembentukan KPI, di mana kehadiran KPI sebagai regulator penyiaran, masih banyak ditolak praktisi dan pengelola penyiaran di Indonesia. Sementara, pada masa sekarang, masih terdapatnya pasal-pasal yang multi tafsir dari berbagai regulasi penyiaran yang dihasilkan KPI menjadi alasan lain masih sering terjadinya pelanggaran terhadap aturan main tersebut. Dibutuhkan ruang terbuka untuk berdialog antara KPI dan stasiun televisi untuk mencari titik temu antara kepentingan yang saling berbeda, untuk kepentingan dunia penyiaran Indonesia yang lebih baik di masa mendatang.

\section{DAFTAR PUSTAKA}

Ardianto, E., \& Komala, L. 2004. Komunikasi Massa: Suatu Pengantar. Bandung: Simbiosa Rekatama Media.

Baksin, A. (2009). Jurnalistik televisi: Teori dan praktek. Simbiosa Rekatama, Bandung 2009.

Baran, J. S., \& Davis, D. K. (2010). Teori komunikasi massa: Dasar, pergolakan dan masa depan. Jakarta: Salemba Humanika.

Ibrahim, I. S. (2004). Penyiaran di Indonesia. Jakarta: Pustaka Bani Quraisy. 
Mufid, M. (2007). Komunikasi \& regulasi penyiaran. Jakarta: Kencana.

Severin, W. J., \& Tankard, J. W. (2008). Teori komunikasi, sejarah, metode dan terapan di dalam mediia massa. Jakarta: Kencana.

Republik Indonesia. (2002). Undang-Undang Republik Indonesia Nomor 32 Tahun 2002. Jakarta: Lembaran Negara Republik Indonesia Tahun 2002 Nomor 139.

Vivian, J. (2008). Teori komunikasi. Jakarta: Kencana. 